Bulletin de la Société Royale des Sciences de Liège, Vol. 86, special issue, 2017, p. 13 - 24

\title{
Evaluation of humic acid application on biochemical composition and yield of black cumin under limited irrigation condition
}

\author{
Siavash ARIAFAR ${ }^{1, *}$, Mohamad FOROUZANDEH $^{2}$ \\ ${ }^{1,2}$ Agricultural Research Institute, University of Zabo, Iran \\ *Corresponding other: avesta.ariafar@gmail.com
}

\begin{abstract}
Black cumin is one of the oldest medicinal plants with scientific name of (Nigella sativa $\mathrm{L}$.). Plants in their growth environment are constantly faced with numerous stresses that limit their chances to develop and survive in one way or another. Drought is one of the stressproducing factors that reduce crops production rate at the global level. Iran has an arid and semi-arid climate and its average rainfall is about one-third of the global average rainfall, so it is faced with drought stresses and periodic droughts. In order to study the effects of irrigation and humic acid on yield, yield components and essential oil composition of black cumin a field experiment was arranged as split plot based on a randomized complete block design with three replications during growing season of 2013-2014. The experiment was conducted a farm located in agricultural research institute of Zabol university in east of Iran. Irrigation intervals (6, 9 and 12 days) and four levels of humic acid concentration $(0,1,2$ and $3 \mathrm{~kg} \mathrm{ha}^{-1}$ ) considered as in main plots and sub-plots, respectively. In this study, seed yield, essential oil percentage were measured and the chemical compositions of essential oil was determined by GC/MS. Results showed that limited irrigation had significant effects on seed yield. With application of humic acid increased seed yield, essential oil percentage, pcymene, gama terpinene and thymoquinone. The highest of p-cymene $24.6 \%$ could be obtained from taking $3 \mathrm{~kg} \cdot \mathrm{ha}^{-1}$ humic acid and the lowest rate $15.4 \%$ was related to not applying humic acid. Also our results indicated that the seed yield ratio under limited irrigation was found to decrease in comparison with the control. According to the results, it appears that application of $3 \mathrm{~kg} \cdot \mathrm{ha}^{-1}$ humic acid was the best treatment in production of yield and essential oil of black cumin in this region.
\end{abstract}

Keywords: Essential oil, Gamma terpinene, Nigella sativa L., Thymoquinone.

\section{Introduction}

The species Nigella Sativa belonging order ranunculales family ranunculaceae. Which is also known as black seed, kala jeera or mangrail. It is used for culinary purposes. However, black seed oil has penetrated boundaries to enter the aromatherapy market due to its wide-ranging health benefits [1-2]. Nigella sativa occupies a major place in the cultures of south east asia and south asia. It serves a wide range of medicinal purposes, which is rendering it increasingly important in the medical world [3]. In addition, it is an integral part of the cuisine of South Asia and South East Asia, used as a flavor for traditional breads. There is a notion that the islamic prophet Muhammad called black seed a major medicinal species. 
Bulletin de la Société Royale des Sciences de Liège, Vol. 86, special issue, 2017, p. 13 - 24

Limited water supply is an important factor affecting growth and metabolic activities of plants. Drought is considered one of the main inhibitors of plants production in many arid and semi-arid regions of the world [4]. The most common environmental stress is drought, which restricts the cultivated land area (25\%) [5], so that in these circumstances, transpiration rate exceeds the amount of water absorption, thereby the water amount is greatly reduced in the plant tissues and cells, as a result of which its growth is reduced or stopped [6]. Due to water shortage, cell volume, cell division, cell wall-making, overall size and of fresh and dry weight of plants are often reduces as general growth factors. One of the first signs of water shortages is a reduced turgor and consequently reduced growth and development of cells, especially in stems and leaves. Cell growth is the most sensitive process that is affected by water shortages. The organ size is limited by a decrease in cell growth and that is why the first tangible effect of dehydration on plants can be identified from the small size of leaves, plants height [7]. Based on the experiment performed on Marjoram (Origanum majorana) plant, it was said that drought stress increases the amount essential oil in this plant [8]. Therefore, plant nutrition management under stress condition is one of the major issues in producing horticultural and agricultural crops [9].

Organic matters are produced as result of biological activities of plants, animals living in the soil which contains all the basic organic components of living or dead, fresh or degraded microorganisms, with the exception of live animals of soil. Bacteria, fungi, like the remains of animal and plant are considered parts of soil organic matter. Organic matters are continuously decayed and degraded and constantly under the attack of soil microorganisms. These materials are often unstable and must be regenerated by adding them continuously to the culture medium. Organic matters consist of two hummus and non-hummus parts. Nonhummus part is not degraded or is slightly degraded. Organic materials, especially the hummus part, are considered the main factor in fertilizing soil, especially in arid areas. Arid and semi-arid soils of our country which constitute more than $(80 \%)$ of agricultural lands are poor in terms of organic matter, as result of which crops growth and yield will be limited. Therefore, it is necessary to add organic materials to agricultural soils to improve their fertility [10]. Humic acid is one of the important fertilizers used in plants. Humic acid is a natural polymer that contains of $\mathrm{H}^{+}$positions related to acidic carboxyl of benzoic and phenolic agents (cation exchange sites) [11]. This acid is an organic complex macromolecule formed by chemical and bacterial phenomena in soil . The final result of the act of humidification, is relatively high molecular weight of stain acid of 104 to 106 Dalton. And $50 \%$ of its molecular weight is composed of carbon [11]. Humic acid can have a direct positive effect on leaf growth. Shoot and root growth is stimulated by humic acid but its effect is more prominent on the root, which increases root volume, and improves the effectiveness of root system [12].

This research was conducted to evaluation of humic acid application on biochemical composition and yield of black cumin under limited irrigation condition in the semi-arid climet.

\section{Materials and methods}

The field experiment was conducted in 2013 and 2014 growing seasons at the Agricultural Research Institute of university of zabol (UOZ), Iran. The experiment is conducted based on a complete randomized block in split plot design with three replicates. Soil Physical and 
Bulletin de la Société Royale des Sciences de Liège, Vol. 86, special issue, 2017, p. 13 - 24

chemical analysis were carried out in the cropping seasons and were shown in table (1) and Humic acid used in table (2). Irrigation intervals: Non stress: (6 days), mild stress: (9 days) and severe stress (12 days) and four levels of humic acid concentration $\left(0,1,2\right.$ and $\left.3 \mathrm{~kg}^{-h^{-1}}\right)$ considered as in main plots and sub-plots, respectively. Seed yield, Percentage of seed essential oil and essential oil compounds were measured in the study. For preliminary and subjective testing was performed by 5 fixed individuals for each treatment. For the isolation and identification of essential oil compounds used GC/MS devices. The specifications of this device are as follows:

Devices GC: Model; Hewlett Packard (HP) 6890, temperature of the injection site: (250 $\left.{ }^{\circ} \mathrm{C}\right)$, thermal planning: 60 to $\left(220^{\circ} \mathrm{C}\right)$, column type: HP- $5 \mathrm{MS}$, carrier gas: helium, gas flow rate: $1 \mathrm{ml}$ per minute, column length: $(30 \mathrm{~m})$, inner diameter: $(250 \mu)$.

Device MS: Model: HO-5973, ionization energy: (70eV).

Table 1: Soil physical and chemical analysis $(0-30 \mathrm{~cm})$

\begin{tabular}{|c|c|c|c|c|c|c|c|c|c|c|c|}
\hline \multirow[t]{2}{*}{$\begin{array}{l}\text { Electrical } \\
\text { conduction }\end{array}$} & \multirow[t]{2}{*}{$\mathrm{pH}$} & Nitrogen & Phosphorus & Potassium & Zinc & $\begin{array}{l}\text { Organic } \\
\text { carbon }\end{array}$ & $\begin{array}{l}\text { Organic } \\
\text { matte }\end{array}$ & Silt & Clay & Sand & \multirow{2}{*}{$\begin{array}{l}\text { Soil } \\
\text { texture }\end{array}$} \\
\hline & & \multicolumn{6}{|c|}{ ppm } & \multicolumn{3}{|c|}{ Percentage } & \\
\hline 1.46 & 8 & 6.3 & 9.2 & 125 & 2.8 & 0.47 & 0.81 & 20.4 & 32.6 & 45 & $\begin{array}{l}\text { clay } \\
\text { loam }\end{array}$ \\
\hline
\end{tabular}

Table 2: View humic acid used in the test

\begin{tabular}{cccc}
\hline Trade name & Fluvic acid & $\mathrm{K}_{2} \mathrm{O}$ & Humic acid \\
\hline HUMAX 95-WSG & $15 \%$ & $5 \%$ & $80 \%$ \\
\hline
\end{tabular}

Table 3: Analysis of variance of quantitative properties of Nigella sativa affected by drought and humic acid

\begin{tabular}{ccccccc}
\hline & & Thymoquinone & Gamaterpinene & p-cymene & $\begin{array}{c}\text { Essential } \\
\text { percentage }\end{array}$ & Seed yieid \\
\hline Repetition & 2 & $11.51^{*}$ & $342.25^{*}$ & $* 33.87$ & $0.039 \mathrm{~ns}$ & $25.331 \mathrm{~ns}$ \\
Drought stress (D) & 2 & $1.84 *$ & $25.74 \mathrm{~ns}$ & $1.74 \mathrm{~ns}$ & $0.112 \mathrm{~ns}$ & $694.76^{* *}$ \\
Main error & 4 & 0.53 & 32.73 & 10.24 & 0.190 & 21.321 \\
Humic acid (H) & 3 & $225.41^{*}$ & $59.26 \mathrm{~ns}$ & $62.24^{* *}$ & 0.543 & $199.87^{* *}$ \\
D×H & 6 & $0.77 * *$ & $75.04 * *$ & $14.03 \mathrm{~ns}$ & $0.029 \mathrm{~ns}$ & $14.899 \mathrm{~ns}$ \\
Sub-errors & 18 & 6.5 & 19.33 & 4.3 & 0.128 & 11.627 \\
\hline CV $(\%)$ & - & 8.5 & 14.3 & 15.2 & 12.9 & 6.9 \\
\hline
\end{tabular}

Identification of compounds was performed according to the output pattern of peaks, their inhibition index and matching those using standard mass spectra available in a computerized library in Mehrazma laboratory in tehran. Essential oil obtained by steam distillation method using clevenger. All data were averaged and statistically analyzed using analysis of variance (ANOVA) by MSTATC and SAS analytical software. The Duncan's multiple range test level was used to compare means. 
Bulletin de la Société Royale des Sciences de Liège, Vol. 86, special issue, 2017, p. 13 - 24

\section{Results and discussion}

\subsection{Seed yield}

Results of variance analysis showed that the effect of drought stress and humic acid on the yield of black cumin seed was significant at the significance level of 1\% (Table 3). According to the comparison made on the data mean, the highest and lowest seed yield was achieved $\left(514.15 \mathrm{~kg} \cdot \mathrm{ha}^{-1}\right)$ from non-stress treatment (every 6 days) and (392.52 kg per ha) related to treatment with severe stress (every 12 days), respectively (Table 4 ). The seed yield was reduced by $(30.99 \%)$ as a result of the stress level and a significant difference was observed between non-stress level and the second level (moderate stress) and third level (severe stress). In an experiment on the effect of different irrigation regimes on the yield and agronomic characteristics of plantago psyllium, it was reported that although its yield was reduced with an increase during irrigation intervals but its mucilage percentage is increased [14].

One of the reasons for this reduction in yield during an increase in drought stress could be due to an increase in photoassimilates allocation to the root compared with the shoot section of the plant [5]. In this context, Reddy et al. [4] reported that moderate water deficit improved the number of umbels per plant as well as the number of umbellets per umbel and the seed yield of cumin (Cuminum cyminum L.) in comparison to the control, but it decreased under severe water deficit. Similarly, drought (irrigation every 12 days) caused a large decrease in seed yield of Nigella sativa and increased thymoquinone percentage under severe water deficit [15]. Also according to results of Forouzandeh et al. [16] on cumin the highest (458.29 kg.ha $\left.{ }^{-1}\right)$ and lowest $\left(146.08 \mathrm{~kg} \cdot \mathrm{ha}^{-1}\right)$ seed yield was produced under the treatments 4 and 2 irrigations times respectively.

Table 4: Mean of some characteristics of Nigella sativa affected by limited irrigation

\begin{tabular}{lcc}
\hline & Thymoquinone & Seed yield \\
\cline { 2 - 3 } Trait & $\%$ & $\mathrm{Kg}^{-1}$ \\
\hline Non stress (control) & $16.6 \mathrm{~b}$ & $514.15 \mathrm{a}$ \\
Mild stress & $22.32 \mathrm{ab}$ & $456.12 \mathrm{~b}$ \\
Severe stress & $29.64 \mathrm{a}$ & $392.52 \mathrm{~b}$ \\
\hline Means followed by similar letters in each column are not significantly different at $\mathrm{p}=5 \%$, Duncan \\
Multiple Range test. \\
$\begin{array}{l}\text { Non stress: (irrigation every } 6 \text { days), Mild stress: (irrigation every } 9 \text { days) and Severe stress } \\
\text { (irrigation every 12 days) }\end{array}$
\end{tabular}

The comparison made on the effect of humic acid on the seed yield showed significant difference between functional levels. The most and lowest seed yield was related to the $(3 \mathrm{~kg})$ per hectare of humic acid treatment $(531.24 \mathrm{~kg}$.ha-1) and related to the control treatment (398.72 kg.ha-1) (without application of humic acid), respectively (Table 5). It showed that the seed yield was improved by $(33.24 \%)$ with the use of 3 kilograms per hectare of humic acid compared with the time humic acid was not used. Heidari and Khalili [17] stated that the highest seed yield was obtained from $1500 \mathrm{~g}$ of humic acid treatment solved in 1000 liters of water with a medicinal plant of Roselle (Hibiscus sabdariffa L.). Heidari and Minaei [18] stated the highest seed yield was obtained from the treatment containing (4.5 liter) of medicinal herb of borage solved in (1000 liters) of water. Furthermore, EI - Khayat [19] 
Bulletin de la Société Royale des Sciences de Liège, Vol. 86, special issue, 2017, p. 13 - 24

found that the $\mathrm{Ca}, \mathrm{S}, \mathrm{Mg}$ and urea application was greater in black cumin grown than the control ones and the percentage of thymoquinone increased significantly under application of this treats.

Table 5: Mean of some characteristics of Nigella sativa affected humic acid levels

\begin{tabular}{lcccc} 
& Thymoquinone & p-cymene & Essential oil & Seed yield \\
\cline { 2 - 5 } Trait & & $\%$ & $1.51 \mathrm{~b}$ & Kg.h $^{-1}$ \\
\hline Humic acid (0) & $17.4 \mathrm{~b}$ & $15.04 \mathrm{~b}$ & $1.74 \mathrm{ab}$ & $413.6 \mathrm{~b}$ \\
Humic acid (1) & $20.98 \mathrm{ab}$ & $21.12 \mathrm{a}$ & $2.09 \mathrm{a}$ & $448.89 \mathrm{~b}$ \\
Humic acid (2) & $27.79 \mathrm{a}$ & $24.61 \mathrm{a}$ & $2.34 \mathrm{a}$ & $531.24 \mathrm{a}$ \\
\hline
\end{tabular}

Means followed by similar letters in each column are not significantly different at $\mathrm{p}=5 \%$, Duncan Multiple Range test

(0): non application, (1): $1 \mathrm{Kg} \cdot \mathrm{h}^{-1}$ application, (2): $2 \mathrm{Kg} \cdot \mathrm{h}^{-1}$ application and (3): $3 \mathrm{Kg} \cdot \mathrm{h}^{-1}$ application

\subsection{Percentage of seed essential oil}

Test results suggest that the effect of drought stress on seed essential oil percentage was insignificant (Table 3). The effect of humic acid on this characteristic was significant at the significance level of 0.5 (Table 3). Based on the comparison made on the data mean, it was found that there was no significant difference among treatments. The most and lowest essential oil percentage of seed was $(2.34 \%)$ with application of humic acid (3 kg.ha-1) and $(1.51 \%)$ of the control treatment (without humic acid), respectively (Table 5). Humic acid is a dense and complex mixture of aromatic organic acids. This compound is composed of sulfur, nitrogen, phosphorus and some metals such as calcium, magnesium, copper, zinc and etc. Humic acid is a biochemically active ingredient of hummus. In fact, humic acid acts similar to other organic fertilizers such as compost, vermicompost and organic fertilizers. According to many reported findings, it was found that use of organic fertilizers helps increase the amount of essential oil in medicinal plant [20], Badran and safwat, 2004).

Azizi and Safai [21] reported that the highest percentage of seed essential oil was obtained from $6 \mathrm{ml} /$ lit humic acid treatment through a foliar spray to black cumin (Nigella sativa L.). The interaction of stress treatments and levels of humic acid was not significant on the amounts of seed essential oil (Table 3).

Our results were in agreement with those obtained by Barghamadi and Najafi [22] on (Carum copticum L .) and Akbari and Gholami [23] on fennel plant. Data presented by Befrozfar et al. [24] indicated that inoculation of biofertilizers, humic acid and vermicompost together or individually via providing suitable substrate for plant establishment and growth can improve photosynthesis that result in basil's dry matter, essence percentage and essence yield increase.

\subsection{Identifying essential oil compounds using GC/MS}

In Graph 1 showed chromatogram of essential oil component of Nigella sativa by GC-MS in $\mathrm{S} 1 \mathrm{H} 4$ treatment. According to the results obtained from these tests, it was found that there are 
Bulletin de la Société Royale des Sciences de Liège, Vol. 86, special issue, 2017, p. 13 - 24

23 compounds in the black cumin essential oil most of which was composed of thymoquinone, $\mathrm{p}$-cymene and gama terpinene (over 50\%) (Table 6).

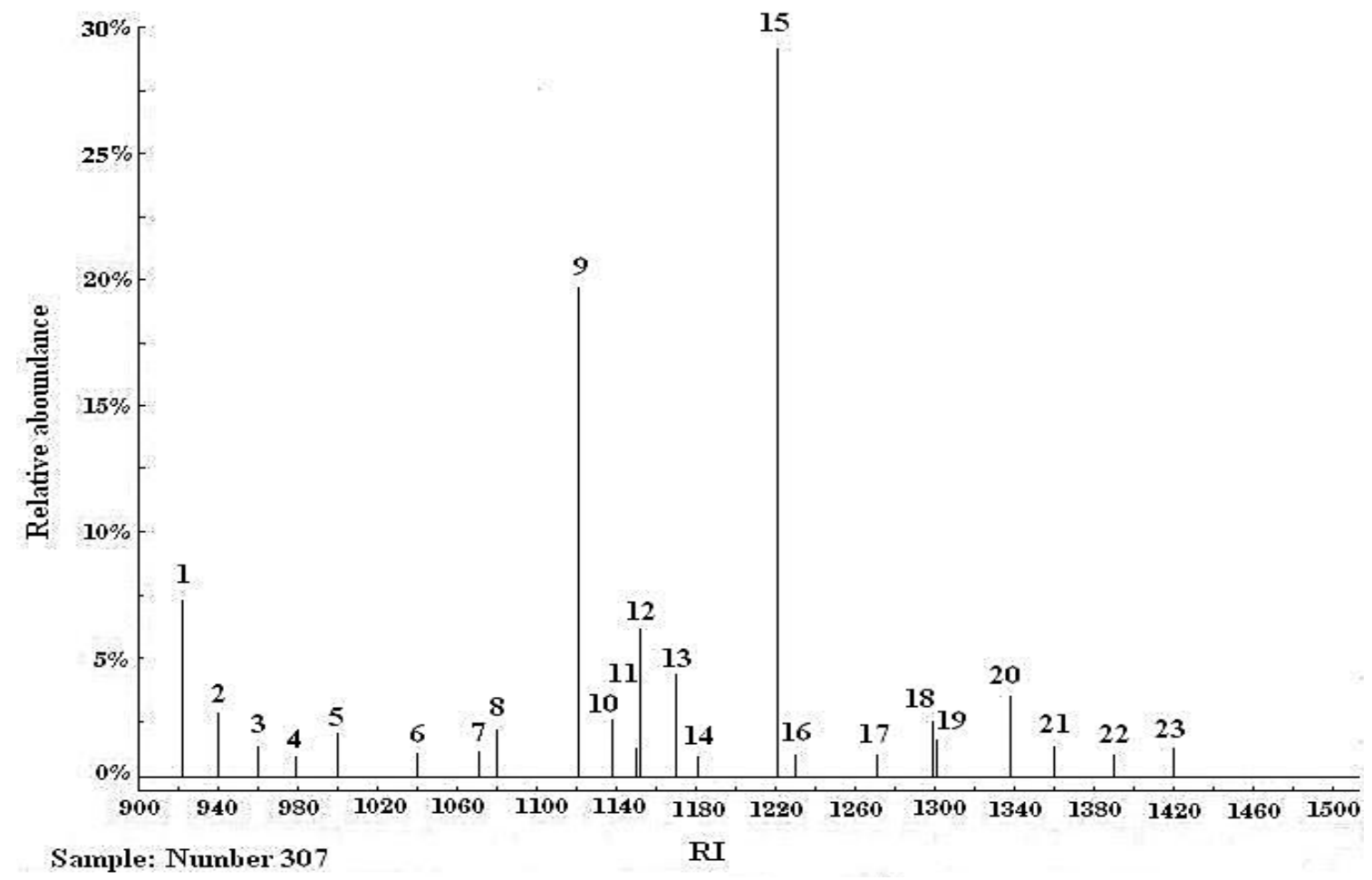

Graph 1: chromatogram of essential oil component of Nigella sativa by GC-MS in S1H4 treatment: $\gamma$-Terpinene (1), Tricyclen (2), B-pinene (3), $\alpha$-pinene (4), Comphene (5),

Sabinene (6), $\beta$-pinene (7), $\alpha$-phellendrene (8), p-cymene (9), $\alpha$-Terpinene (10), Limonene (11), $\beta$-Ocymene (12), Linalool (13), Borneol (14), Tymoquinon (15), Trans-

Dihydrocarovone (16), Terpinolene (17), Spathulenol (18), Thymol (19), Carvacrol (20), 1methoxymeth (21), $\beta$-Caryophyllen (22), Alpha-bisabolol oxid (23).

RI: Rotation Index

S1H1: Irrigation every 6 days and non-application 
Bulletin de la Société Royale des Sciences de Liège, Vol. 86, special issue, 2017, p. 13 - 24

Table 6: Percentage of essential oil components in Nigella sativa affected by drought stress and humic acid

\begin{tabular}{|c|c|c|c|c|c|c|c|c|c|c|c|c|c|c|}
\hline \multirow{2}{*}{$\begin{array}{c}\text { Peak } \\
\text { numbe } \\
\text { r }\end{array}$} & \multirow{2}{*}{ Essential oil components } & \multirow{2}{*}{ RI } & \multirow{2}{*}{$\frac{\mathrm{S} 1 \mathrm{H} 1}{\%}$} & \multirow{2}{*}{$\frac{\mathrm{S} 1 \mathrm{H} 2}{\%}$} & \multirow{2}{*}{$\frac{\text { S1H3 }}{\%}$} & \multirow{2}{*}{$\frac{\mathrm{S} 1 \mathrm{H} 4}{\%}$} & \multirow{2}{*}{$\frac{\mathrm{S} 2 \mathrm{H} 1}{\%}$} & \multirow{2}{*}{$\frac{\mathrm{S} 2 \mathrm{H} 2}{\%}$} & \multirow{2}{*}{$\frac{\mathrm{S} 2 \mathrm{H} 3}{\%}$} & \multirow{2}{*}{$\frac{\mathrm{S} 2 \mathrm{H} 4}{\%}$} & \multirow{2}{*}{$\frac{\mathrm{S} 3 \mathrm{H} 1}{\%}$} & \multirow{2}{*}{$\frac{\mathrm{S} 3 \mathrm{H} 2}{\%}$} & \multirow{2}{*}{$\frac{\mathrm{S} 3 \mathrm{H} 3}{\%}$} & \multirow{2}{*}{$\frac{\mathrm{S} 3 \mathrm{H} 4}{\%}$} \\
\hline & & & & & & & & & & & & & & \\
\hline 1 & $\gamma$-Terpinene & 895 & 5.1 & 4.02 & 5.9 & 7.05 & 6.6 & 4.65 & 4.15 & 5.2 & 5.95 & 6.45 & 6.95 & 4.55 \\
\hline 2 & Tricyclen & 924 & 2.75 & 2.59 & 1.65 & 3 & 1.9 & 1.8 & 1.6 & 1.8 & 1.15 & 1.45 & 1.15 & 1.3 \\
\hline 3 & B-pinene & 940 & 1.5 & 1.54 & 1.75 & 2.7 & 1.5 & 1.3 & 1.7 & 2.3 & 1.35 & 1.6 & 1.4 & 1.1 \\
\hline 4 & $\alpha$-pinene & 951 & 1 & 1.32 & 1.05 & 1.3 & 1.8 & 1.3 & 1.7 & 1.3 & 1.55 & 0.45 & 0.55 & 0.9 \\
\hline 5 & Comphene & 978 & 1.15 & 1.31 & 2.1 & 2.75 & 1.7 & 1.8 & 1.55 & 0.8 & 1.05 & 1.4 & 1.5 & 1.25 \\
\hline 6 & Sabinene & 992 & 1 & 1.32 & 1 & 1.1 & 1.5 & 0.7 & 1.2 & 0.7 & 0.45 & 0.95 & 1 & 1.1 \\
\hline 7 & $\beta$-pinene & 1076 & 1.2 & 1.52 & 1.55 & 1.4 & 1.1 & 1.2 & 1.25 & 1.2 & 1.05 & 1.15 & 0.3 & 0.5 \\
\hline 8 & $\alpha-$ phellendrene & 1089 & 2.05 & 1.93 & 1.15 & 2.65 & 1.9 & 1.3 & 1.1 & 2.3 & 1.15 & 1.05 & 1.4 & 1.4 \\
\hline 9 & p-cymene & 1120 & 23.7 & 22.46 & 22.35 & 26.85 & 22.4 & 20.2 & 23.6 & 15.6 & 23.5 & 20.9 & 19.5 & 20.35 \\
\hline 10 & $\alpha$-Terpinene & 1137 & 2.05 & 1.9 & 2 & 2.6 & 2 & 2.1 & 2.6 & 2.1 & 1.01 & 2.62 & 1.83 & 1.59 \\
\hline 11 & Limonene & 1151 & 1.05 & 1.01 & 1.1 & 1.5 & 0.8 & 1.9 & 1.9 & 1.7 & 1.95 & 1.5 & 1.1 & 0.75 \\
\hline 12 & $\beta$-Ocymene & 1159 & 3.5 & 3.31 & 4.8 & 6.5 & 4.3 & 3.15 & 3.4 & 3.1 & 2.8 & 2.45 & 2.1 & 2.85 \\
\hline 13 & Linalool & 1169 & 3.7 & 3.42 & 2.4 & 4.7 & 3.4 & 2.55 & 2.8 & 2.7 & 2.35 & 1.45 & 2.3 & 1.8 \\
\hline 14 & Borneol & 1177 & 0.8 & 0.66 & 1.7 & 1.45 & 0.9 & 0.6 & 0.8 & 1.3 & 1.8 & 1 & 1.1 & 0.25 \\
\hline 15 & Tymoquinon & 1189 & 23.6 & 27.76 & 26.8 & 30.9 & 17.4 & 19.25 & 28.6 & 30.1 & 19.3 & 17.6 & 19.55 & 20.4 \\
\hline 16 & Trans-Dihydrocarovone & 1199 & 0.8 & 0.9 & 0.9 & 1.1 & 1.6 & 0.99 & 1.2 & 1.1 & 1.05 & 0.98 & 0.76 & 0.85 \\
\hline 17 & Terpinolene & 1205 & 1.7 & 1.42 & 1.1 & 1.3 & 1 & 1.2 & 1.85 & 0.9 & 0.55 & 1.6 & 0.45 & 0.15 \\
\hline 18 & Spathulenol & 1210 & 1.2 & 1.28 & 1.5 & 1.15 & 1.3 & 0.85 & 1.25 & 0.6 & 1.2 & 1.8 & 1.45 & 1.95 \\
\hline 19 & Thymol & 1236 & 1.9 & 1.1 & 1 & 2.6 & 1.5 & 1.6 & 1.4 & 1.7 & 1.5 & 1.6 & 1.3 & 1 \\
\hline 20 & Carvacrol & 1270 & 2 & 2.2 & 3 & 3.4 & 2.8 & 2.4 & 1.3 & 1 & 1.4 & 1.5 & 1.5 & 2.4 \\
\hline 21 & 1-methoxymeth & 1291 & 1.9 & 1 & 0.8 & 1.3 & 1.1 & 0.92 & 0.8 & 1.3 & 0.7 & 0.9 & 0.8 & 1 \\
\hline 22 & $\beta$-Caryophyllen & 1309 & 1 & 1.2 & 0.8 & 1.4 & 0.9 & 1.1 & 1.5 & 0.7 & 0.85 & 1.2 & 1 & 0.4 \\
\hline 23 & Alpha-bisabolol oxid & 1322 & 1.4 & 1.1 & 1 & 1.5 & 1.3 & 0.8 & 0.7 & 0.9 & 1.1 & 1.7 & 0.9 & $0 / 76$ \\
\hline
\end{tabular}

S1H1: Irrigation every 6 days and non-application, S1H2: irrigation every 6 days and $1 \mathrm{Kg} \cdot \mathrm{h}^{-1}$ application, S1H3: irrigation every 6 days and 2 $\mathrm{Kg} \cdot \mathrm{h}^{-1}$ application, S1H4: irrigation every 6 days and $3 \mathrm{Kg} \cdot \mathrm{h}^{-1}$ application, S2H1: irrigation every 9 days and non-application, S2H2: irrigation every 9 days and $1 \mathrm{Kg} \cdot \mathrm{h}^{-1}$ application, S2H3: irrigation every 9 days and $2 \mathrm{Kg} \cdot \mathrm{h}^{-1}$ application, S2H4: irrigation every 9 days and $3 \mathrm{Kg} \cdot \mathrm{h}^{-1}$ application, $\mathrm{S} 3 \mathrm{H} 1$ : irrigation every 12 days and non-application, $\mathrm{S} 3 \mathrm{H} 2$ : irrigation every 12 days and $1 \mathrm{Kg} \cdot \mathrm{h}^{-1}$ application, $\mathrm{S} 3 \mathrm{H} 3$ : irrigation every 12 days and $2 \mathrm{Kg} \cdot \mathrm{h}^{-1}$ application, S3H4: irrigation every 12 days and $3 \mathrm{Kg} \cdot \mathrm{h}^{-1}$ application. 


\subsection{Constituent compounds of essential oil}

\subsection{1. p-cymene}

According to the results of data analysis, it was found that humic acid treatment had a significant effect on the cymene amount of the black cumin essential oil (Table 3). The results presented in the table of means comparison, showed that the highest and lowest amounts of P-cymene were observed in $\left(2 \mathrm{~kg} \mathrm{ha}^{-1}\right)$ of humic acid treatment (24.61) and in the treatment without humic acid treatment per ha (15.04), respectively (Table 5). Stress drought treatments as well as interaction between humic acid and stress had no significant effect on the amount of cymene (Table 3 ).

These results are slight different from the work reported by Sunita et al [25] who reported that p-cymene $(31.2 \%)$ and thymoquinone $(37.6 \%)$ were the major components of black cumin. Singh et al. [26] and Singh and Kamal [27] also reported p-cymene as the major component in the black cumin essential oil.

\subsubsection{Gamma terpinene}

Results of variance analysis showed that the amount of gamma terpinene was significant under the influence of the interaction between humic acid and stress drought in the level of (1\%) (Table 3). According to the results obtained from the interaction among treatments, the highest and lowest amounts of gamma terpinene was obtained $(7.85 \%)$ from $3 \mathrm{~kg}$ per hectare of humic acid treatment + non drought stress and from the $\left(1 \mathrm{~kg} \cdot \mathrm{ha}^{-1}\right)$ of humic acid treatment + severe drought stress $(5.2 \%)$, respectively (Figure 1 ).

\section{no stress mild stress $\quad$ severe stress}

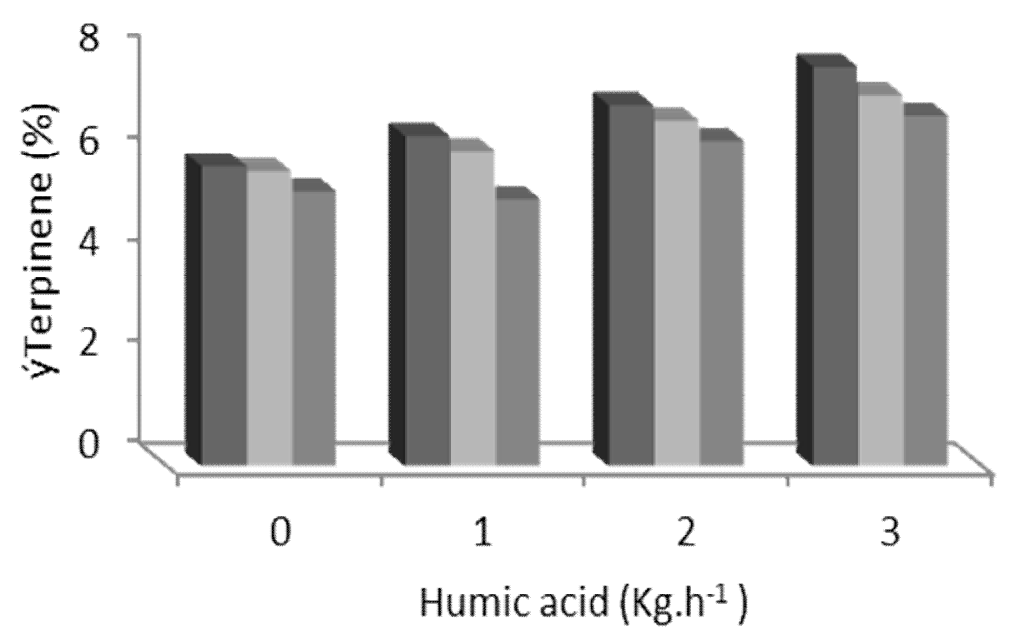

Figure 1: Gamaterpinen percentage in essential oil of Nigella sativa affected by drought and humic acid. 


\subsubsection{Thymoquinone}

The amount of thymoquinone in essential oil was significant at the level of (1\%) due to the effect of humic acid treatments and drought stress. Also, the interaction of humic acid treatments and drought stress was significant on the amount of thymoquinone of the essential oil at the level of (5\%) (Table 3).

The results of interactions among treatment showed that the highest and lowest amounts of thymoquinone were obtained from the $\left(3 \mathrm{~kg} \cdot \mathrm{ha}^{-1}\right)$ of humic acid treatment + non- drought stress $(32.1 \%)$ and the control humic acid treatment+ severe drought stress $(16 \%)$, respectively (Figure 2). The results of Sunita et al. [25] showed that thymoquinone, pcymene (monoterpene), longifolene (sesquiterpene), and thymohydroquinone were responsible for strong antimicrobial activity of black cumin oil.

These findings could be used to prepare multipurpose products for pharmaceutical applications and its usage as dietary source of antioxidant should be considered largely for alleviating and ameliorating diseases.

nostress mild stress $\square$ severe stress

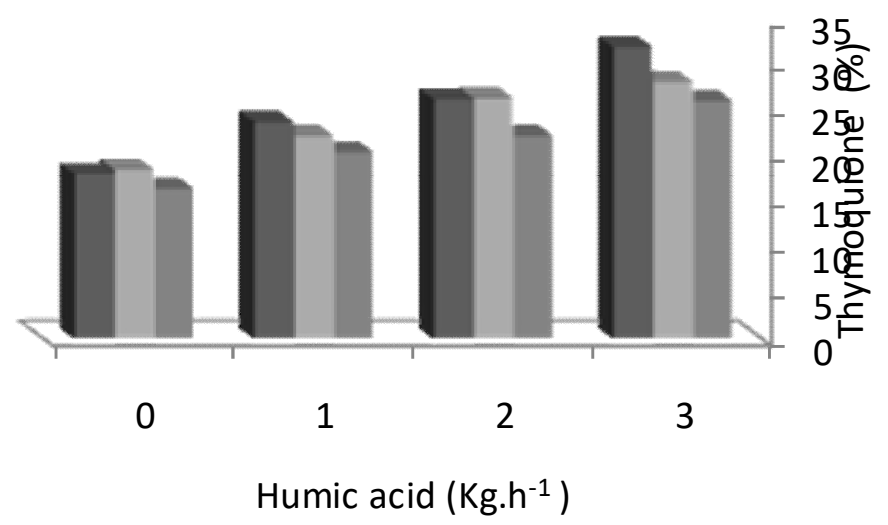

Figure 2: Thymoquinone percentage in essential oil of Nigella sativa affected by drought and humic acid.

Results of Akbari and Gholami [23] study showed that vermicompost and humic acid application and also mycorrhizal colonization, improved the quantitative and qualitative yield of fennel (Foeniculum vulgar MiLL). So, the seed yield, essence yield and root colonization significantly affected by fertilizer treatments. These factors without causing environmental damage, provide nutrients for medicinal plants, therefore improved the yield and quality [28]. According to the results obtained from this experiment, it can be concluded that high levels of humic acid increased thymoquinone, P-cymene and gammaterpinene in the black cumin. Thymoquinone belongs to phenolic group. Considering the finding that the most plant height, number of capsules per plant, number of seeds per plant, biological yield, grain yield, essential oil percentage, seed yield, total chlorophyll and the amount of nitrogen, phosphorus and potassium in seed are also obtained as result of $\left(3 \mathrm{~kg} \cdot \mathrm{ha}^{-1}\right)$ of humic acid treatment, and 
also clear and proven role of these two substances in increasing growth and yield of the plant in different ways, such as developing the root system and helping better absorption of nutrients, it can be concluded that, at best state of growth and yield, the amount of thymol in essential oil was at its greatest extent in this plant. Here, it may possible that some elements absorbed by the plant played an important role in this respect.

Now, we will have a quick review on the role of some elements in the biosynthesis of essential oils. Nitrogen, phosphorus and potassium are involved in the growth and biosynthesis of the essential oil. In addition to the effects on photosynthesis and respiration to produce carbonaceous skeletons (Pyruvate) necessary for the biosynthesis of essential oil, they participate in the structure of 3 important coenzymes named ATP, NADP/ NADPH and coenzyme A (CoA) that have a major role in the biosynthesis Terpenoids [29]. Much of the biological activity of the Nigella seeds has been shown to be due to thymoquinone, the major component of the essential oil [30].

Within a single species 5000 to 20000 individual primary and secondary compounds may be produced. Despite the enormous variety secondary metabolites, the number of biosynthetic pathways related to these compounds is restricted and distinct. Precursors required for glycolysis and shikimate pathway are derived. In other words, primary metabolites are prerequisite for the synthesis of secondary metabolites. For example, carbohydrates, glycosides, resins and mucilage are obtained from aromatic amino acids phenols, tannins, and from aliphatic amino acids aromatic alkaloids. As it can be considered, the maximum amount of bioactive molecules found in the essential oil of black cumin, belongs to phenols and thymoquinone. Also, P-cymene and gamma terpinene that are considered the most important terpenes in the essential oil, were at their greatest extent in best state of growth and yield.

\section{Conclusio}

The variations in black cumin quality between this treats were possibly due to difference in environmental conditions, nutrient, soil type, soil moisture percentage and irrigation time leading to different shoot growth rates and biochemical composition in the shoots. The basic components of Nigella sativa were thymoquinone, gamma terpinene and p-cymene that have a high proportion than other components.

\section{References}

[1] Paarakh, P. M., 2010. A comprehensive review Nigella sativa Linn. Indian Journal of Natural Products and Resources, 1(4): 409-429.

[2] Salem, M. L., 2005. Immunomodulatory and therapeutic properties of the Nigella sativa L. seed. International Immunopharmacology, 5(13): 1749-70.

[3] Bourgou, S., R. Ksouri, A. Bellila, I. Skandrani, H. Falleh, B. Marzouk, 2008. Phenolic composition and biological activities of Tunisian Nigella sativa L. shoots and roots. Comptes Rendus Biologies, 331(1): 48-55.

[4] Redd, A. R., K. V. Chaitanya, M. Vivekanandan, 2004. Drought-induced responses of photosynthesisand antioxidant metabolism in higher plants. Journal of Plant Physiology, 161(11): 1189-1202. 
[5] Christiansen, M. N., C. F. Leevis, 1982. Breeding plants for less favorable environments. John Wiley and Sons, New York.

[6] Koochaki, A., G. H. Sarmadnia, 1990. Crop Physiology. SID Publications of Mashhad. Iran.

[7] Hsiao, T., 1973. Plant responses to water stress. Plant Physiology, 24: 519-570.

[8] Ardakani, M. R., B. Abbaszadeh, E. Sharifi Ashourabadi, M. H. Lebaschi, F. Packnejad, 2007. The effect of water deficit on quantitative and qualitative characters of balm (Melissa officinalis L.). Iranian Journal of Medicinal and Aromatic Plants, 23(2): 251-261.

[9] Mohammadkhani, N., R. Heidari, 2007. Effects of water stress on respiration, photosynthetic pigments and water content in tow Maize cultivar. Pakistan Journal of Biological Science, 10(22): 4022-4028.

[10] Malakouti, M., M. Homaei, 1994. Productivity of drylands. Tarbiat Modarres University of Tehran press, $\mathrm{p} 450$.

[11] Sardashti, A., M. Alidoost, 2007. Determination and Characterization of Chemical Composition of the Humic Acid from Forest Soil of North of Iran. 15th conference of Crystallography and mineralogy in iran. Ferdowsi Univrsity of Mashhad. (13-14, Feb, 2007, Iran). p 361.

[12] Sabzevari, S., H. Khazaei, M. Kafi, 2009. Effect of humic acid on on the growth of roots and shoots of Sabalan and Saionz wheat cultivars. Journal of Water and Soil, 23(2): 87-99.

[13] Samsam shariat, S. H., 2003. Medical plant propagation. Mani press, p 422.

[14] Najafi, F., P. Rezvani moghadam, 2002. Effects of different irrigation regimes and density on yield and agronomic characteristics of Plantago psyllium. Iranian Journal of Field Crop Science, (2): 16-26.

[15] Ghorbanali, M., A. Babaei, P. Babakhanloo, M. Mirza, 1999. Effect of water stress on Nigella sativa L. growth and development, quality and quantity of essential oil, and amount of seed oil. Iranian Journal of Agricultural Sciences, 30(3): 585-593.

[16] Forouzandeh, M., M. A. Karimian, Z. Mohkami, 2014. Effect of water stress and different type of organic fertilizers of essential oil content and yield components of Cuminum cyminum. Indian Journal of Fundamental and Applied Life Sciences, 4(3): 533-536.

[17] Heidari, M., S. Khahlil, 2014. Effects of Humic Acid and Phosphorus Fertilizer on Seed and Flower Yield, Photosynthetic Pigments and Mineral ElementsConcentration in Sour Tea (Hisbiscus sabdariffa L.). Iranian Journal of Field Crop Science, 45(2): 191-199.

[18] Heidari, M., A. Minaei, 2014. Effects of drought stress and humic acid application on flower yield and content of macro-elements in medical plant borage (Borago officinalis L.). Journal of Plant Production Research, 21(1): 167-182.

[19] EI - Khayat, A. S. M., H. A. H. Gouda, 2005. Effect of application of ca, s,Ma and urea on growth, yield and chemical composition of (Nigella sativa L.) plants. Annals of Agricultural science, 43: 1271-1294.

[20] Atiyeh, R. M., S. Subler, C. A. Edwards, G. Bachman, J. D. Metzger, W. Shuster, 2000. Effects of vermicomposts and compost on plant growth in horticultural. Container media and soil pedobiologia, 44: 579-590.

[21] Azizi, M., Z. Safai, 2013. The effect of humic acid foliar and Nano fertilizer on oil yield and essential oil of Black Cumin (Nigella sativa L.). The first national conference of 
medicinal plant and sustainable agriculture. Shahid Mofateh University of Hamedan. (10, October, 2013). P. 52-63. http://www.iscconferences.ir/422/fa

[22] Barghamadi, K., S. H. Najafi, 2015. Effect of Different Levels of Nitroxin and Humic Acid on Quantitative Properties and Essential Oil of Ajowan (Carum copticum L.) C. B. Clarke). Journal of Horticultural Science, 29(3): 332-341.

[23] Akbari, I., A. Gholami, 2016. Evaluation of Mycorrhizal Fungi, Vermicompost and Humic Acid on Essence Yield and Root Colonization of Fennel. Iranian Journal of Field Crops Research, 13(4): 840-853.

[24] Befrozfar, M. R., D. Habibi, A. Asgharzadeh, M. Sadeghi-Shoae, M. R. Tookalloo, 2013. Vermicompost, plant growth promoting bacteria and humic acid can affect the growth and essence of basil (Ocimumbasilicum L.). Annals of Biological Research, 4 (2): 8-12.

[25] Sunita, S., S. S. Das, G. Singh, C. Schuff, M. P.de. Lampasona, C. A. N. Catalán, 2014. Composition, In Vitro Antioxidant and Antimicrobial Activities of Essential Oil and Oleoresins Obtained from Black Cumin Seeds (Nigella sativa L.). Bio Med Research International, Feb 6. 1-10.

[26] Singh, G., P. Marimuthu, C. S. De Heluani, C. Catalan, 2005. Chemical constituents and antimicrobial and antioxidant potentials of essential oil and acetone extract of Nigella sativa seeds. Journal of the Science of Food and Agriculture, 85(13): 2297-2306.

[27] Singh, R. K., N. J. Kamal, 2014. Chemical composition of volatile oil of Nigella sativa seeds. World Journal of Pharmacy and Pharmaceutical Sciences, 3(10). 1588-1594.

[28] Darzi, M.T., A. Ghalavand, F. Rajali, 2008. Study the effects of mycorrhiza, vermicompost and biophosphate on flowering, biological yield and colonization of Foeniculum vulgar MiLL. Journal of Iraniann Crop Science, 10(1): 88-109.

[29] Sell, C. S, 2003. A Fragrant Introduction to Terpenoid Chemistry. The Royal Society of Chemistry, Thomas Graham House, Science Park, Milton Road, Cambridge. UK, $\mathrm{P} 410$.

[30] Pirasa, A., A. Rosab, B. Marongiua, S. Porceddaa, D. Falconieric, M. A. Dessìb, B. Ozcelikd, U. Kocae, 2013. Chemical composition and in vitro bioactivity of the volatile and fixed oils of Nigella sativa L. extracted by supercritical carbon dioxide. Industrial Crops and Products, 46: 317-323. 